\title{
Cactus (Opuntia ficus-indica): Current Utilization and Future Threats as Cattle Forage in Raya-Azebo, Ethiopia
}

\author{
Nigus Gebremedhn Abay (Corresponding author) \\ Department of Geography \& Environmental Studies \\ Dire-Dawa University, PO Box 1362, Dire-Dawa, Ethiopia \\ E-mail: nigusabay@gmail.com
}

Received: March 14, 2018 Accepted: March 30, 2018 Published: May 18, 2018

doi:10.5296/emsd.v7i3.12806 URL: https://doi.org/10.5296/emsd.v7i3.12806

\begin{abstract}
The increased importance of cactus as livestock feed in arid and semiarid zone is due to its availability during critical dry months of the year. Availability of feeds for livestock is a major constraint to livestock production in drylands of Ethiopia, specifically Tigray region. This study was conducted in Maru dryland areas of Raya-Azebo, Tigray region of Ethiopia. The purpose of the study was to generate information on current and future utilization of cactus as cattle feed in minor and severe drought episodes. The study has employed multiple qualitative methods that include focus group discussion, key informant interview, field observation and review of relevant literature. The study result conveyed livestock feed shortage are caused by frequent drought, degradation of grazing land by increased number of animals and human population. Accordingly, in dry spells and drought times, mostly March to June the local farmers are highly depend on cactus as supplementary animal forage. Due to the increased frequency of drought and animal feed shortage draught oxen and lactating cow are primarily fed on cactus of other livestock types. The process of cactus preparation and cattle feeding is tough task because it takes enormous time and labor. Nevertheless of its role, the future use of Opuntia ficus-indica is threatened by farmland expansion, prevalence of cochineal insect, and increased number of camel. Therefore, for sustainable usage of Opuntia ficus-indica in the future further study on control of cochineal insect and promotion of cactus planting on degraded lands is recommended.
\end{abstract}

Keywords: Cactus, Cattle, Feed Shortage, Cactus feeding, Maru Kebelle 


\section{Introduction}

Different authors have clearly underlined the importance of Opuntia as it become an endless source of products and functions, initially as a wild plant and, later, as a crop for both subsistence and market-oriented agriculture, contributing to the food security of populations in agriculturally marginalized areas (Stephen G. and Enrique A., 1995; Barbera et al., 1995).

Opuntia has been cultivated for its fruit worldwide and is adapted to semi-arid and arid conditions. Opuntia has adapted perfectly to arid climate which are usually manifested with droughty conditions, erratic rainfall and poor soils subject to erosion. They thus contribute in times of drought, serving as lifesaving crops for both humans and animals (Stephen G. and Enrique A., 1995; FAO, 2005; Russell and Felker, 1987; Felker and Inglese, 2002; Shoop et al., 1977). The importance of opuntia as a forage plant in the back time was the outcome of the need to feed livestock in the arid areas, where the dry seasons are very long (Anaya-Perez, 2002). Subsequently, there is increasing interest in opuntia and opuntias ficus-indica in particular, and the important role they play and are likely to play in the success of sustainable agricultural systems in arid and semi-arid zones, where farmers and herds must look to those few species that can profitably survive and produce. Additionally, Opunitia fcus-indica is considered to be high in in-vitro digestibility and in water content and it is often the only source of green forage in the dry season (Silva and Santos, 2007).

The increased importance of cactus as livestock feed in arid and semiarid zones is due to its drought resistance, high biomass yield, and high palatability, ease of propagation, persistency, high digestibility, and tolerance to salinity. In many arid areas, farmers use cactus extensively as an emergency forage that is harvested from both wild and cultivated stands to prevent the disastrous consequences of frequent and severe droughts (Nefzaoui \& Ben Salem, 1996; Tegegne, 2001). Opuntia ficus-indica production for forage is variable, because the production techniques used are very poor and in most cases it is grown wild. Prickly pear cactus utilization as a forage for livestock has been mainly due to its availability during critical dry months of the year (Fuentes-rodriguez, 1997; Ben Salem and Smith, 2008). Despite its suitability as an alternative source of livestock feed, cactus plants are fragile and should not be grazed directly by animals a practice that could be highly destructive and drastically shorten the longevity of cactus plantations (FAO, 2014).

A lot of researches, reports, conferences and workshops have widely documented and discussed about the growing environmental challenges of pastoral system in Ethiopia. Among the major difficulties the system has been facing is the recurrent drought with its devastating effects on the rangelands, livestock, and the general livelihood of pastoralists ("SOS Sahel Ethiopia," n.d.)

In the dryland parts of Ethiopia cactus has covered a total of 331000 hectares (ha) of land, of which 31000 ha is cultivated while 300000 ha is naturalized (Zimmermann, Bloem, \& Klein, 2004). Tigray, a region in north Ethiopia, is a semi-arid area with limited agricultural potential, and is also well known for its livestock resource with critical feed shortage. More than $85 \%$ of the population in the region lives in rural areas with their main source of livelihood based on agriculture. In turn, agricultural production is hampered by unreliable 
rainfall and ever increasing human and livestock pressures. Moreover, livestock production in such environments also faces challenges due to feed shortage (Gebreegziabher Z. and BA Tsegay, 2015). Owing the natural and cultivated or homestead grown cactus species, in Ethiopia it is considered as a 'Bridge of life' because the stems and fruit store large quantities of water and provide both feed for cattle in times of drought and food for livestock herders, so contributing to the survival of both farmers and their animals (SAERT, 1994). There is increasing reliance on in reducing drought induced impacts by consuming cactus pearl for animal and its fruit for human feed (Mengistu et al., 2016).

Mixed farming is the dominant livelihood to the community of Raya-Azebo, where livestock keeping is a mainstay and means of generating income and securing food for a long time. However, since the recent past, due to recurrent drought livestock herding is challenged by acute shortages of feed supplies. Maru kebelle $e^{1}$ the area where the study conducted is one of the most drought prone areas in Raya-Azebo woreda ${ }^{2}$. The climatology data of the woreda indicates rainfall is unreliable and recurrent drought is a major problem and thereby it is creating seasonal feed resources shortage (Raya-Azebo Woreda Agricultural Office, 2017). Therefore, the purpose of this study was to generate information on current and future utilization of cactus by local farmers in combating cattle feed shortage.

\section{Methods and Materials}

\subsection{Study Area}

This study was carried out in Maru Kebelle which is one among the 13 Kebelles found in Rara-Azebo woreda, Tigray region of Ethiopia. It is inhabited with 7869 total population and composed of four nucleated villages namely Baso, Maru, Daraita and Kilota. The kebelle has a total of 18493 livestock population. Geographically, is situated in latitude and longitude of $12^{0} 25^{\prime} 05^{\prime \prime}$ and $12^{0} 31^{\prime} 15^{\prime \prime}$ North and $39^{0} 38^{\prime} 10^{\prime \prime}$ and 39 $44^{\circ} 20^{\prime \prime}$ East respectively (Fig. 1.).

The study site has a total area of 6485 ha of which 2899.74 ha is agricultural land, 1990 ha is covered with open woodland vegetation and the remaining belongs to communal grazing land and bare land. The average temperature is $22.5^{\circ} \mathrm{c}$ while the mean annual rainfall is $559 \mathrm{~mm}$ (Kebelle Agricultural office, 2017). The principal cereal crops in the Woreda are Sorghum and Teff.

\footnotetext{
${ }^{1}$ Kebelle: Smallest administrative unit in Ethiopia

2 Woreda: Administrative unit higher than Kebelle
} 
Table 1. Maru Kebelle Livestock population profile

\begin{tabular}{|l|l|l|l|}
\hline S/No & Livestock type & Kebelle Livestock Population & Woreda Livestock Population \\
\hline $\mathbf{1}$ & Cattle & 11463 & 205218 \\
\hline $\mathbf{2}$ & Sheep & 2218 & 57041 \\
\hline $\mathbf{3}$ & Goat & 2816 & 58441 \\
\hline $\mathbf{4}$ & Mule & 163 & 822 \\
\hline $\mathbf{5}$ & Horse & 3 & 96 \\
\hline $\mathbf{6}$ & Donkey & 880 & 114760 \\
\hline $\mathbf{7}$ & Camel & 950 & 15696 \\
\hline $\mathbf{8}$ & Total & 18493 & 348790 \\
\hline
\end{tabular}

Source: Raya-Azebo woreda Office of Agriculture, 2017

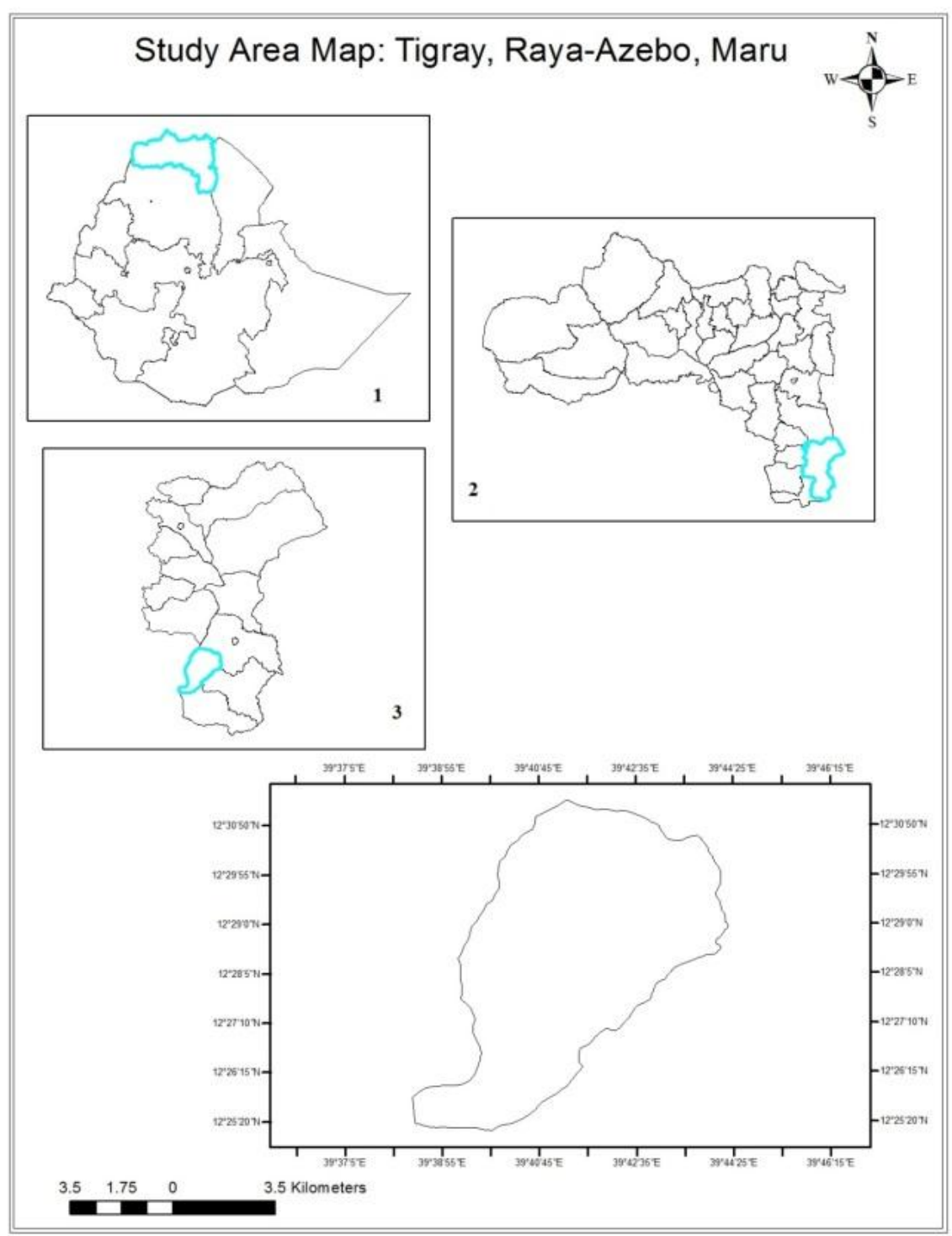

Figure 1. Study Area Map 


\subsection{Study Approach}

Maru kebelle was selected purposively for the study based on its experience in cactus feeding to combat the commonness of animal feed shortage. A single-visit-multiple subjects formal survey technique (ILCA, 1990) was used to collect data. Accordingly, the study has employed multiple qualitative methods that include focus group discussion (FGD), key informant interviews, field observation and review of relevant literature.

With the help of chairperson of the Kebelle and development agent experts sample farmers for FGD and interview were chosen purposively. FGD participants were selected from a mixed group of society including herders, women, elders, clan leaders and experienced persons. Hence, four FGD sessions, one in each nucleated villages were conducted having 12 participants. Additionally, key informant interview were carried out with a total of 20 experience rich elders composing five from each of the nucleated villages. Additionally, observation was used to gather first hand data. During observation, field notes and photographs of some important situations and practices were taken.

Finally, after collecting the expected necessary data using different instruments from respondents and office reports, data analysis was accomplished using thematic description and narration. In analyzing the recent changes on land cover from grazing to farmland Q-GIS2.18.12 and Arc-GIS 10.1 softwares were employed.

\section{Result and Discussion}

Animal feed shortage is a common and serious problem in the woreda and specifically in the study site. To this end, the Raya herders are using Opuntia ficus-indica to minimize animal feed shortage. The finding of the study in combating the problem is discussed here below.

\subsection{Current Utilization of Cactus as Forage}

According to the response of the farmers interviewed, in the study Kebelle herders depend on the rain-fed natural grazing land to raise their livestock. Feed and water resources for livestock on these grazing lands vary with changing weather conditions. Water and feed qualities and quantities are low in the dry season mostly (March to June) and lowest during drought period. Therefore, main livestock feed resources in the study sites were natural pastures, crop residues and cactus cladodes. For the greater part of the year, communal grazing lands barely meet the forage requirements of animals.

cactus pear's potential in cattle feed in Maru Kebelle as an emergency feedstock in drought periods was started after the 1985-1986 major drought which hit the study area and Ethiopia at large. After wards the great famine cactus had become very valuable resource and drawn the attention of majority of the society as it becomes the major supplementary animal feed source in the critical times of prolonged dry seasons. Hence, cactus has planted and grown as an alternative drought resilient feed resource by majority of the community. Likewise, currently almost all farmers' compound and backyard is fenced with cactus and every household is believed to own 60-90 meter dimension of cactus fence.

Results from FGD revealed that cactus cladodes feeding for livestock will differ according to 


\section{Macrothink}

circumstances, such as number of animal holding, quantity of preserved crop residues, cactus availability, fuel wood availability and onset of next rainy season (Table 2). The farmers have ranked rainfall distribution, cactus availability and cattle holding as major factors determining the period of cactus feeding. Based on the above variables cactus feeding calendar varies one to five months per year. Both in minor and severe drought times draught oxen milking cow and weak or injured animals primarily fed on cactus. The farmers averagely provide six to eight cladodes of cactus per day per ox or cow and commonly, they supply 40 to 60 cladodes to their cattle daily. Generally, the Raya community are practicing cactus feeding in peak feed shortage recorded months of the year from March to June.

Further, results from focus group discussions and individual interviews indicated the process of cactus feeding was a tough and harsh task which requires enormous time and patience. Ahead of months of cactus feeding the preparation starts with searching and collection of firewood. The quantity and average time spent for firewood collection is still determined by number of cattle holding, length of the dry season and crop residue availability. Then owing the spiny nature of the fleshy cactus cladodes the next task was burning of cladodes in an open fire until it becomes clean of the spines (Fig. 2.).

Burning cladodes was performed every day or every other day in the early morning before the Sun gets stronger. Since, the farmers believe cooling the burned cactus reduces cattle bloating and diarrhea the spiny cleaned cladodes were covered with new spiny cactus all the day. Lastly, all the time in the late afternoon the burned and cooled cladodes sliced with sickle and made ready to feed by animals (Fig. 3.).

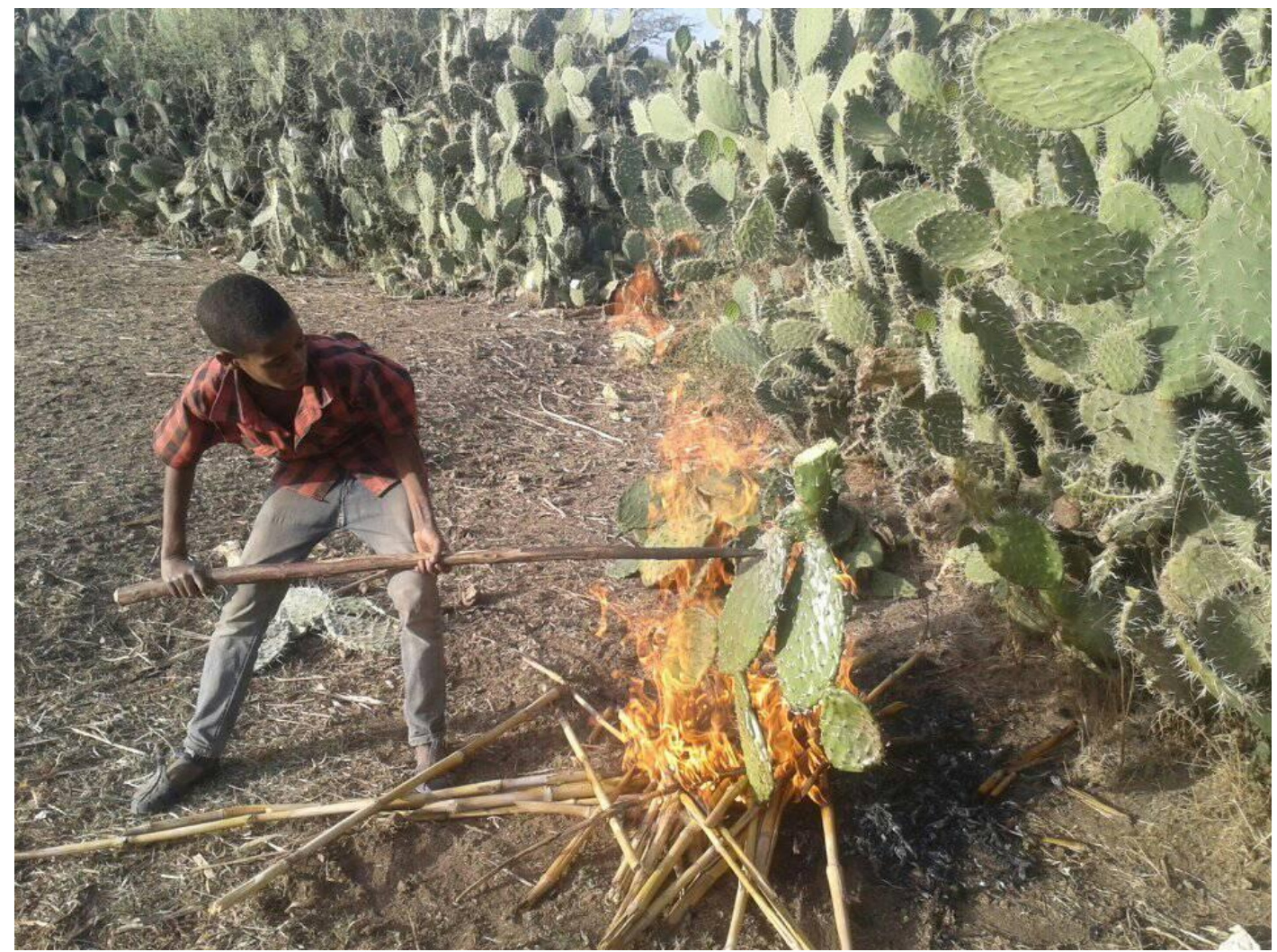

Figure 2. Burning cactus spines in an open fire 


\section{Macrothink}

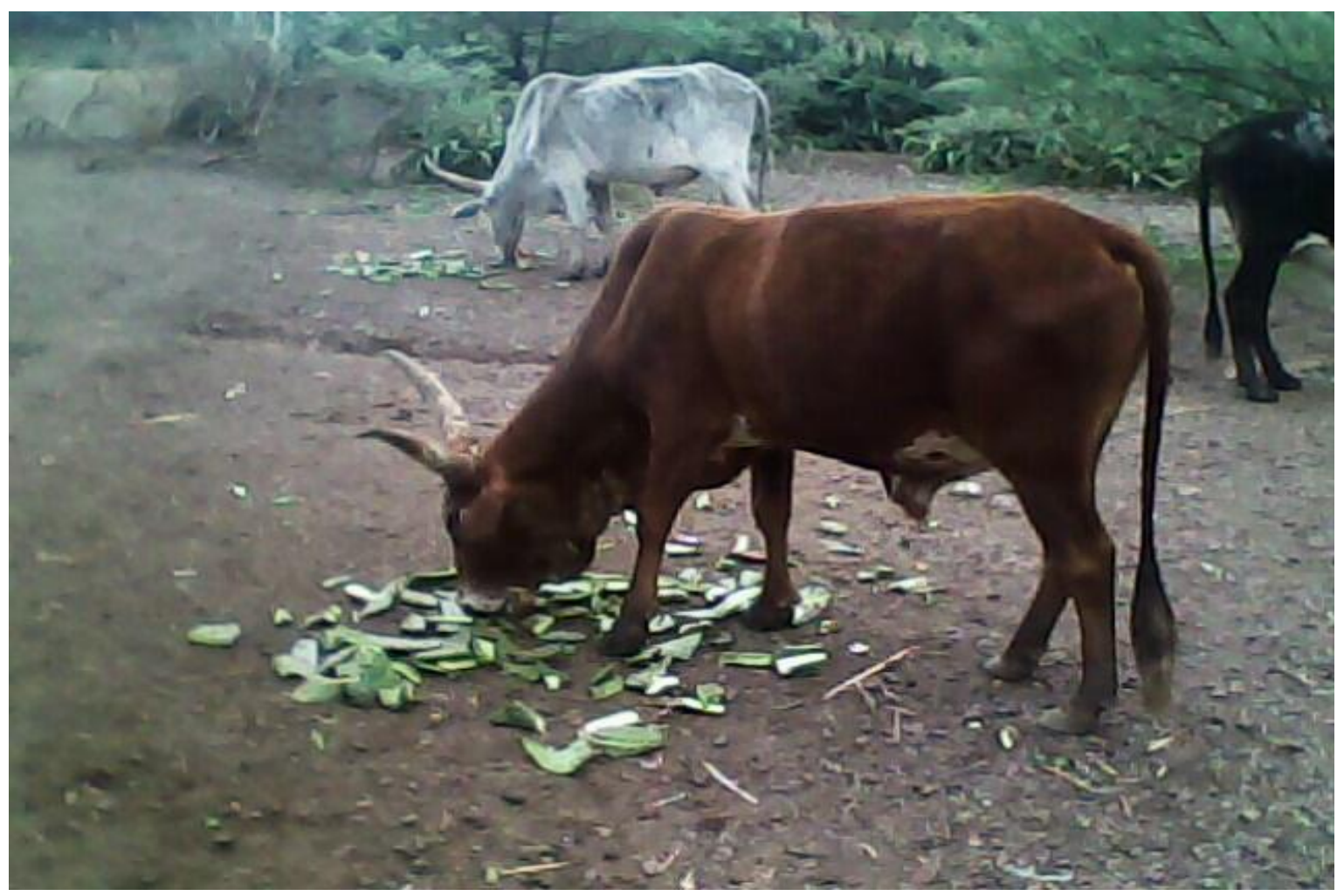

Figure 3. Cattle feeding on chopped cactus

Cactus feeding alone does not provide a sufficient diet for animals, due to limited crude protein of approximately 5\% and it raises loose stool on livestock. Therefore, it is necessary to combine high fiber diet options, like combination of crop residues (Syomiti, Chirchir, Duyu, \& Dana, 2009). In the study area crop byproducts was collected and preserved as a contingency for the upcoming dry season aiming to provide balanced forage in times of cactus feeding. Cattle diarrhea or loos stool following cactus feeding was also managed by supplement cattle feed on sorghum and maize stalks, teff $f^{3}$ hay, and by reducing the watering frequency of cattle. In general, participants have perceived in times of peak animal feed shortage cactus feeding is the ultimate safeguard mainly to poor farmers. The woreda had also confirmed the cactus is the utmost animal feed in bad rainy times and helps in reducing number of animal loss following long dry seasons.

\subsection{Future Threats of Cactus as Forage}

Worldwide cacti experience a diverse range of threats, the predominant processes that is the direct human activities responsible for the degradation, destruction and/or impairment of cacti were land conversion to agriculture and aquaculture, collection as biological resources, and residential and commercial developments (Goettsch et al., 2015). Similarly, the participants in the study site were asked to prioritize threats on future usage of cactus as animal feed and their perception is discussed as follows.

\footnotetext{
${ }^{3}$ Teff: cereal crop in Ethiopia, its scientific name is Eragrostis tef
} 


\section{Macrothink

\subsubsection{Prevalence of Cochineal Insect}

Of the big challenges observed by localities regarding the fate of cactus feeding was the fast demolition of cactus by prevalence of cochineal insect specifically in Daraita and Baso nucleated villages. Previous study also confirmed, cochineal insect affects cladodes and decrease the feeding potential of the plant to animals and humans and currently the insect is invading vast areas of Tigray region and is out of control in the southern zone of the region where this study is conducted (Gebremeskel G., 2013).

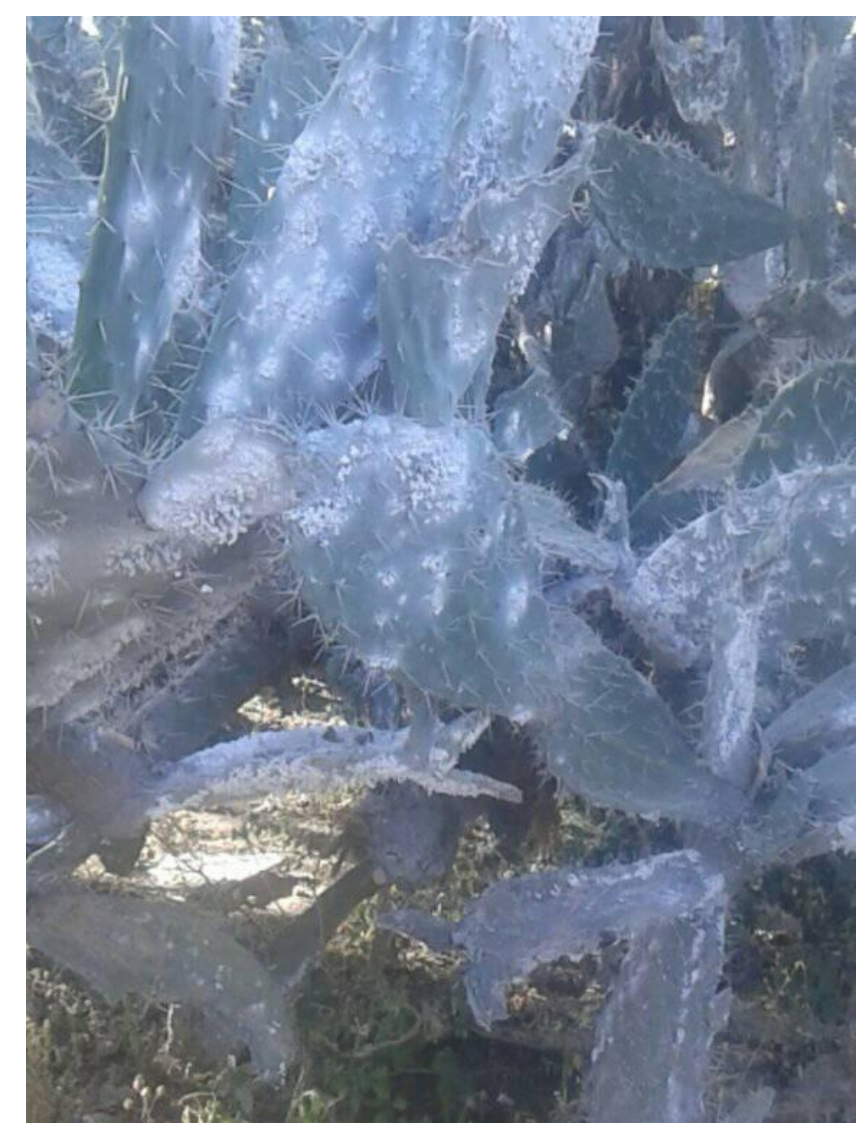

Figure 4. Cactus affected by cochineal insect

\subsubsection{Farmland Expansion}

Based on the 2007 census of Ethiopia, the total human population of Raya-Azebo woreda was 136039 and recently on 2017 it has reached about 164000. On the other hand, seven years back on 2011 cattle population of the Raya-Azebo woreda was 195484 while in 2017 it has reached 205218 whereas the communal grazing land covered 5616.4 ha out of 176684 ha which is the total area coverage of the woreda (Raya-Azebo Woreda Agricultural office, 2017). Correspondingly, at this time cactus covers about 18328 ha of the woreda land cover type. Agricultural office report of the woreda stated the rising number of human and livestock population and existence of recurrent drought has accentuated deterioration of pasture quality and quantity.

During the focus group discussion in Daraita village farmers reported that, agriculture is the 


\section{Macrothink}

most widespread threat to wild cacti distribution in large parts of the study area. Likewise, the data from local agricultural office indicated recently on 2014 about 67.5 ha of land has distributed to 270 new married couples and unemployed youngsters (Fig. 5.). Therefore, a considerable increase in the number of people in in the study area has resulted in a significant proportion of the grazing land being used for crop production in the small holder sector and there has been a general shortage of land for grazing. Consequently, the recent land use change made in the study area is meaningful to indicate the likely threat on cactus abundance and distribution.

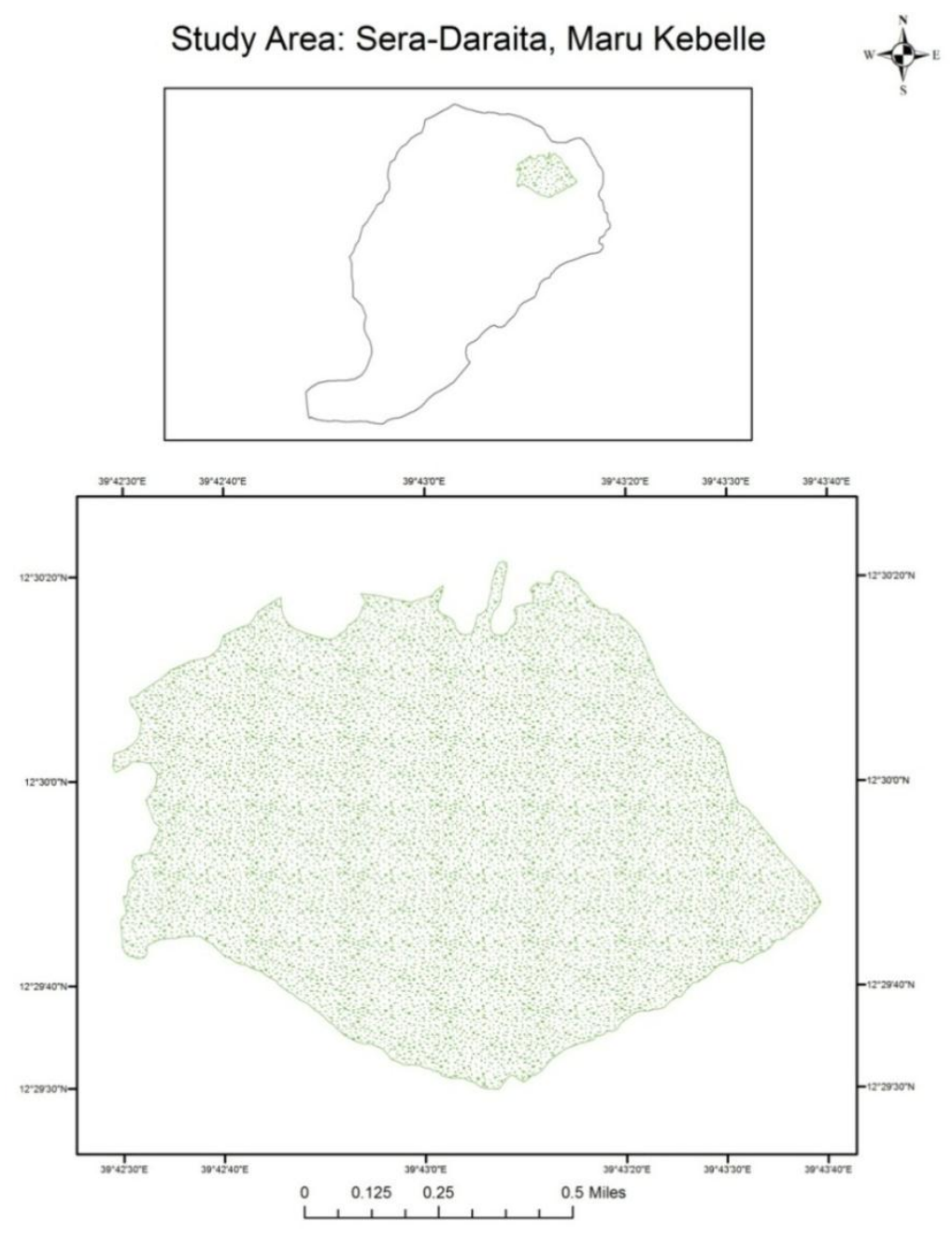

Figure 5. Recent land cover change

The recent land use and land cover change is clearly indicated on certain areas of the tudy site. The Google earth satellite image (figure 6) represent two temporal images 2013 and 2017, on 2013 the area on map was grazing land but later 2017 onwards it has converted to farmland. 

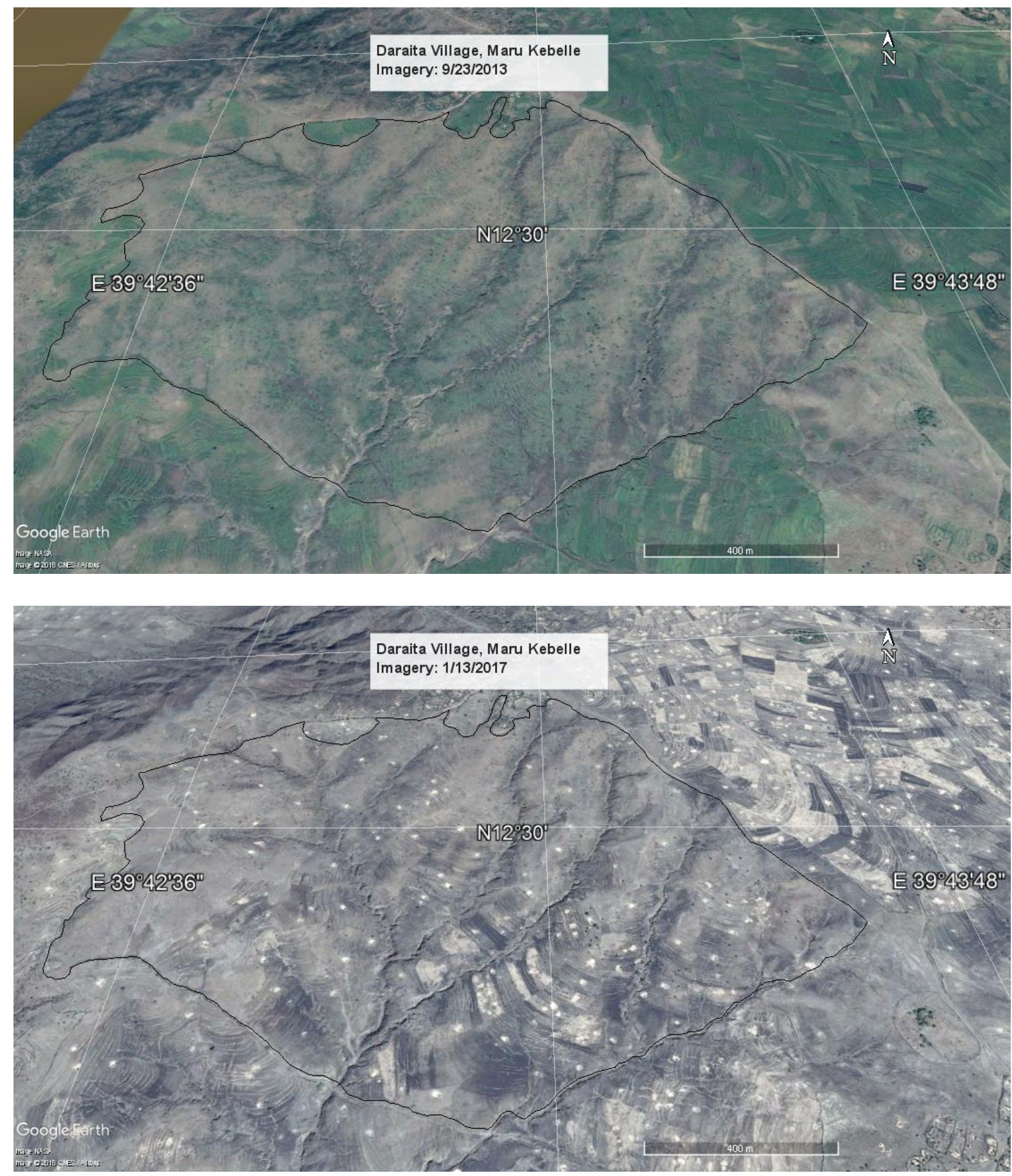

\subsubsection{Herd Composition Change}

The communal cactus field is also ruined and is under greater pressure due to increased animal feed shortage. Consequently, destocking of and changing cattle herd to camel and small ruminant is practiced by larger number of society. The recent livestock data of the Kebelle indicates the number of camel population has reached 950 (Table 1). Hence, the increasing number of camels had brought rapid utilization and destruction of cactus because 
camels are capable of browsing early cladodes and spiny cactus as well.

\subsubsection{Rising Price of Cactus}

Farmers with large number of animal holding are facing extra problems especially in extended drought times as they are forced to destock their animals or purchase private cactus standing. According to the FGD participants for three months contract usage, 40-50 meter horizontal length of cactus fence having 1-3 meter height has been sold 900-1500 Eth Birr ${ }^{4}$ which is equivalent to (33-55 USD).

\section{Conclusion}

This study has assessed the existing experience in cactus utilization as an animal feed especially in the prolonged dry seasons and the future threat in Maru Kebelle of Raya-Azebo. Cactus pear's potential in cattle feed in Raya-Azebo as an emergency feedstock in drought periods was started after the 1985-1986 major drought which hit the study area. In times of minor and severe drought times and annually cactus feeding reaches its peak March to June. Draught oxen and milking cow are primarily fed on prepared cactus in minor and severe drought occurrences. As a result, the role of cactus as major supplementary forage in bridging animal feed shortage was found significant. Beyond the role played the future availability of cactus in the study site is dwindling majorly by farmland encroachment and cochineal insect. Once if the prevalence of the insect becomes out of control, it will be difficult, very expensive and uneconomical to rescue the resource. Consequently, for viable usage Opuntia ficus-indica rehabilitation of degraded lands with cactus is highly desired.

Hence, based on the results of this study, the following recommendations are given so as to be considered in the future intervention strategies which are aimed at the promotion of cactus usage as emergency animal feed. Since, cactus is easy and cheap to grow, palatable, and able to withstand prolonged droughts therefore, it has to be planted in severely degraded areas. Additionally, government and Non-governmental organizations working on dryland areas has to pay work on the way to maximize the role of cactus. Finally, further study on the prevention and control of the cochineal insect is mandatory.

\section{Acknowledgements}

The author acknowledges Mr. Ambachew B., Mr. Haftu G. and Mr. Mesele A. for their cooperation in providing all necessary data. Additionally, Key informants and FGD participants are highly acknowledge for sharing their valuable time and knowledge.

\section{References}

Anaya-Perez, M. A. (2002). History of the use of opuntia as forage in Mexico. Cactus (Opuntia Spp.) as Forage. FAO Plant Production and Protection Paper, 169, 5-12.

Barbera, G., Inglese, P., \& Pimientabarrios, E., (1995). Agro-Ecology, Cultivation and Uses of Cactus Pear. In FAO Plant Production and Protection, Paper 132. Rome, Italy.

\footnotetext{
${ }^{4}$ Eth Birr: Ethiopian Currency
} 
BenSalem and Smith. (2008). Feeding strategies to increase small ruminant production in dry environments. Small Ruminant Research, 77, 174-194.

https://doi.org/10.1016/j.smallrumres.2008.03.008

FAO. (2005). Fertilizer use by crop in South Africa, Rome, Italy. [Link]

http://www.fao.org/docrep/008/y5998e/y5998e06.htm\#bm06.

FAO. (2014). Promoting Cactus as an alternative and sustainable livestock feed. In Cactusnet. https://doi.org/10.13140/RG.2.1.3935.7604

Fuentes-rodriguez, J. (1997). Feeding prickly pear cactus to small ruminants in Northern Mexico. I. Goats. Journal of the Professional Association for Cactus ..., (1981), 1992-1995. Retrieved from http://jpacd.org/downloads/Vol2/4_UCLF.pdf

Gebreegziabher, Z., \& Tsegay, B. A. (2015). Efficacy of cactus pear (opuntia ficus-indica) varieties as a source of food and feed in endamehoni district, northern ethiopia. Affrican journal of food, agriculture, nutrition and development, 10406-10427.

Gebremeskel, G., Getachew, A., \& Firew, T. (2013). Assessment of the potential of cactus pear (Opuntia ficus indica) as livestock feed in Northern Ethiopia [Link] http://www.lrrd.org/lrrd25/2/moen25026.htm. Livestock Research for Rural Development.

Goettsch, B., Hilton-Taylor, C., Cruz-Piñón, G., Duffy, J. P., Frances, A., Hernández, H. M., ... Gaston, K. J. (2015). High proportion of cactus species threatened with extinction. Nature Plants, 1(10), 15142. https://doi.org/10.1038/nplants.2015.142

ILCA. (1990). Livestock system research manual No.12, section 1. Working document. International Livestock Center for Africa, Addis Ababa, Ethiopia.

Mengistu, Kefelegn, K., \& Gebretnsae, W. M. (2016). Effects of Supplementing Cactus Cladode and Acacia Senegal Branches on Intake, Digestibility and Body Weight Gain of Tigray Highland Sheep Fed Barley Straw. Journal of Fisheries \& Livestock Production, 4(3). https://doi.org/10.4172/2332-2608

Nefzaoui, A., \& Ben Salem, H. (1996). Effect of increasing level of spineless cactus (Opuntia ficus-indica var. inermis) on intake and digestion by sheep fed straw-based diets. Anim. Sci.

Felkeer, P., \& Inglese, P. (2002). Short-term and long-term research needs for Opuntia fcus-indica (L.) Mill. Utilization in arid areas. Journal of the Professional Association for Cactus Development, 5, 131-152.

Russel, P., \& Felker, C. (1987). The prickly-pears (Opuntia spp., Cactaceae): A source of human and animal food in semiarid regions. Economic Botany, 41, 433-445.

https://doi.org/10.1007/BF02859062

SAERT. (1994). Cactus as supplementary food and forage support component of SAERT. Sustainable Agriculture and Environmental Rehabilitation in Tigray.

Shoop, M. C., Alford, E. J., \& H. F. M. (1977). Plains prickly pear is a good forage for cattle. Journal of Range Management, 3, 12-16. https://doi.org/10.2307/3897325 


\section{Macrothink}

Environmental Management and Sustainable Development

ISSN 2164-7682 2018, Vol. 7, No. 3

Silva, C. C. F., \& Santos, L. C. (2007). Palma Forrageira (Opuntia fcus-indica Mill) como alternativa na alimentação de ruminantes. REDVET, 8(5), 1695-7504.

SOS Sahel Ethiopia. (n.d.) Pastoralism in Ethiopia: Its total economic values and development challenges.

Stephen, G., \& Enrique, A. (1995). Opuntia as Forage, 1-36.

Syomiti, M., Chirchir, S., Duyu, J., \& Dana, H. (2009). Feeding spineless cactus to cattle for drought resilience, Kenya Margaret, 1-5.

Tegegne, F. (2001). Nutritional value of Opuntia ficus-indica as a ruminant feed in Ethiopia. Cactus (Opuntia Spp.) as Forage, 91-100.

Zimmermann, H., Bloem, S., \& Klein, H. (2004). Biology, history, threat, surveillance and control of the cactus moth, Cactoblastis cactorum.

\section{Copyright Disclaimer}

Copyright for this article is retained by the author(s), with first publication rights granted to the journal.

This is an open-access article distributed under the terms and conditions of the Creative Commons Attribution license (http://creativecommons.org/licenses/by/3.0/). 